\title{
PRINCIPLES OF ISLAMIC INTERNATIONAL LAW
}

\section{The Principle of Equality}

\subsection{Equality before the Law}

The principle of equality constitutes one of the most important principles of Islamic international law. ${ }^{1}$ The definition of the principle of equality in Islamic international law is, to some extent, different to that of public international law. The principle of equality is, in the latter, an innovation and was not therefore dealt with in its early history. ${ }^{2}$ Equality in the system of public international law is, basically, used in two connections. One is in the case of states and their equality under the system and the other is expressed in the instruments of international human rights law and mostly refers to equality between individuals or groups.

Islamic international law basically uses the word equality in connection with individual equality and the use of the word in the case of states is only an exemption. ${ }^{3}$ This is because Islamic international law places, a heavy weight and full respects, on individual rights and duties and for these reasons, individuals constitute the most important subjects of its system. ${ }^{4}$ According to Islamic international law, no individual is above

1 The Qur'ān, 49:13.

${ }^{2}$ Historically, the system of public international law did not accept states and nations on equal footings and categorized them due to the circumstances. Some states were recognised as full sovereign, some half sovereign and certain others as barbarous. Yet, colonialization of states and nations was one of the consolidated subjects dealt with in the law of nations. Even a considerable number of the rules of the United Nations deal with colony states and eventually the way in which they may receive freedom due to the conditions of the colonial powerful states. This has however, juridically, been settled. Philosophically, the situation is different.

${ }^{3}$ It is therefore the basic idea of Islam to develop the personality of an individual and his/her responsibility before the creator.

${ }^{4}$ According to one writer, 'The modern law of nations presupposes the existence of a family of nations composed of a community of states enjoying full sovereign rights and equality of status. The Muslim law of nations recognises no other nation than its own, since the ultimate goal of Islam was the subordination of the whole world to one system 
another, and any priority given to individuals in this world is superficial, and has no spiritual value. It is on this basis that the principle of equality in Islamic international law, contrary to that of public international law, is in essence, the expression of equality of rights between individuals. In other words, since the establishment of the United Nations, the use of the term equality within public international law has been to express equality between states (and within the area of human rights law for individuals and groups) while the principle of equality in Islamic international law is a legal right of individuals and not a right which has been given by the state. This right to equality has been established since the revelation of Islamic jurisdiction. ${ }^{5}$ The equality between subjects of the law also constitutes one of the main elements of Islamic international law. This original legal theory of Islamic law and Islamic international law has also been greatly effective in the Western concept of international law. ${ }^{6}$ Moreover, 'it was the Muslims who ... not only developed international law, the first in the world, as a distinct discipline, but also ... made it form part of the law instead of politics. ${ }^{7}$

of law and religion. Furthermore, the Muslim law of nations was ordinarily binding upon individuals rather than territorial groups. For Islamic law, like all ancient law, had a personal rather than a territorial character and was obligatory upon the Muslims, as individuals or as a group, regardless of the territory they resided in.' Khadduri, War and Peace in the Law of Islam, pp. 44-45.

Contrary to the above conclusion, it is to be noticed that Islamic international law recognises other nations and this is clearly stated in the Qur'ān. It reads that 'We created you from a male and female, and formed you into nations and tribes that you may recognise each other.' The Qur'ān, 49:13.

${ }^{5}$ Khadduri, War and Peace in the Law of Islam, p. 46.

6 There are, in fact, different opinions concerning the legal and political effect of Islamic law on Western international law in general and the Western legal system in particular. On the positive effect of Islamic law in various Western legal systems see C.G. Weeramantry, Islamic Jurisprudence: An International Perspective (1988), pp. 149158. According to Professor Weeramantry, for example, "In relation to the vital discipline of international law there was no literature from Greece and Rome comparable to their literature in private law. We do not have treatises dealing with such questions as the binding force and interpretation of treaties, the duties of combatants, the rights of non-combatants or the disposal of enemy property. The only body of literature in this discipline was the Islamic." Moreover, "Arabic literature was ... not a great unknown in the days when the first seeds were being sown of what was to become Western international law." Id., p. 150. On the impact of Islamic international law upon Grotius thoughts see id., pp. 150-158. See also Justice Jackson, forword to Law in the Middle East, edited by Majid Khadduri (1955).

7 Publications of Centre Culturel Islamique-Introduction to Islam, p. 94. 


\subsection{The Basic Source of Equality}

The basic source of equality under Islamic international law is different from that of public international law. According to the latter, the theory and norms of equality extend from states to individuals whilst in Islamic international law from individuals to states. The effect of this difference is that in public international law, equality between individuals widely depends on the existence of equality between states, and if we suppose that states are not willing to accept one another on an equal footing, the concept of equality between individuals of those states will not be in balance. This was demonstrated by the start of the Second World War when the priorities of certain races over others were proved during the war. The German Jew and those who were originally the citizens of other states in Europe were genocided. This was based on the fact that the concept of equality was methodological in nature and not spiritual in essence. $^{8}$

The principle of equality in Islamic international laws developed from the equality of individuals and therefore the concept of equality of states in Islamic international law constantly depends on whether equality between individuals is fully respected by certain authorities. Accordingly, a policy of non-equality between states can never be effective in the implementation of the principle of the equality of individuals. According to the second source of Islamic law "The Arab has no superiority over the non-Arab and the non-Arab has no superiority over the Arab. All are children of Adam and Adam was made of earth." Thus, the equality of individuals must be seen, as one of the strong and important principles from which the different concepts of equalities are developed. These include social, economic and political equality. ${ }^{10}$

8 The question is also much sensible in the case of the position of individuals before the permanent International Criminal Court. This is because one of the principles of the court is to prosecute and punish all individuals who have committed international crimes. The principle is applicable, regardless of the nationality or position of individuals. However, the government of the United States has signed certain treaties with several states, in order not to prosecute its individuals who are accused of committing international crimes. Instead, they are to be handled to the United States. The policy of the treaties of this kind is against the principle of equality of individuals before international criminal courts. It also demonstrates that the concept of equality between individuals may be superficial. Examine part III.

${ }^{9}$ Weeramantry, p. 172.

${ }^{10}$ However, one should not disagree with the fact that the principle of equality of individuals in Islamic law has seriously been violated in many Islamic states. Clear 


\subsection{Equality in Sex}

The principle of the equality of individuals in Islamic international law also extends to the principle of equality between males and females, tribes, nations and states. ${ }^{11}$ In this connection the Qur'ān reads that 'O men, We created you from a male and female and formed you into nations and tribes that you may recognise each other. He who has more integrity has indeed greater honour with God.' ${ }^{12}$ It is for this reason that Islamic international law prohibits all forms of discriminations and privileges on the basis of race, nationality, language, religion, geographical location and so forth.

The above elements of Islamic international law emanating from the principle of equality have existed since its revelation and therefore its jurisdiction from an historical point of view takes priority over the relevant principle of public international law governing the equality of gender. However, one cannot disagree with the fact that that the question of equality of gender has continuously been violated by most Islamic nations. This has made a serious difficulty in the identification and interpretation of the above-mentioned verse. At the same time, one cannot disagree either with the fact that until the middle of the 2oth century and even up until today, the question of equality of gender has not been solved within the principles of international law practically. The question of gender equality is one of the most important issues of worldwide perspective and one of the most serious problems between Muslim nations today.

\section{The Principle of Peace}

\subsection{Peaceful Relations}

Islam should mean peace. ${ }^{13}$ Islamic international law bases its international relations on the principle of peace between all nations and states. Common and reciprocal understandings of conflicts are the two chief

\footnotetext{
examples of these violations are in the Islamic Republic of Iran, the Kingdom of Saudi Arabia, the Socialist People's Libyan Arab Jamahiriya, the Arab Republic of Egypt and the dynastic Muslim Monarch Kuwait where the principle of inequality is strongly practised between individuals, and human rights norms are constantly ignored.

${ }^{11}$ See also below, the principle of reciprocal respect.

12 The Qur'ān, 49:13.

13 This has however not been respected by Islamic states.
} 
elements for the peaceful settlement of disputes. The principle of peace therefore constitutes one of the most important principles of Islamic international law in order to achieve justice and cooperation for the solving of international conflicts. The principle of peace also coincides with the principle of peaceful co-existence and both of these present, more or less, the same ideology of peaceful relations. ${ }^{14}$

The difference between them relies on the fact that the principle of peace encourages the settlement of international conflicts with peaceful methods while the principle of peaceful co-existence draws attention to the fact that even though, there may be, between two or more nations, certain political, ideological or even theological conflicts, they should still encompass peaceful international relations. This should be regardless of conflicts basically arising from different interpretations of the same subject matter and being of mutual or multilateral interests. Moreover, its primary significance is the 'making of peace' and the idea of 'peace is the dominant idea in Islam. ${ }^{15}$ Islamic international law thus promotes reciprocal obligations and duties and due to its philosophy of justice consent constitutes the main principle for obedience to the law and to the peace. According to this philosophy no force should be employed for the implementation of Islamic law. ${ }^{16}$ Rules and obligations must come into existence through peaceful relations and not by ideological or military force.

\subsection{Peace As a Duty}

Contrary to interpretations made by some European writers, Islamic international law does not encourage war between states. It respects all states on an equal footing, but, based on mutual respect. ${ }^{17}$ Islamic international law is, thus, against waging war in international relations and an aggressive war is prohibited according to its basic provisions. ${ }^{18}$ More importantly, wars should be ended as quickly as possible and the

\footnotetext{
14 This principle was developed by the communist states during the Cold War. It denotes the possibility of creating international relations between two different ideologies.

${ }^{15}$ Muhammad Ali Maulvi, Islam the Religion of Humanity (1926), p. 4; See also Maulana Muhammad Ali, Back to the Qur'ān, Back to Muhammad, Rise! Advance! (1926), p. 19; Muhammad Ali, Islam or the Natural Religion of Man: A Brief Sketch of Its Principles as given in the Holy Qur'ān (1912), pp. 3-5.

${ }^{16}$ It is a well know fact in the Qur'ân that 'Let there be no compulsion in religion.'

17 The Qur'ān, 49:13.

${ }^{18}$ See chapter on aggression.
} 
conflicting parties should work for peace and its implementation. Having peaceful international relations is consequently a duty of all Muslim states and this should not be violated for political, theoretical, economical or any other reasons.

As a matter of fact, Islamic law employs the word duty in many contexts clarifying the moral and legal responsibilities of individuals. It is in this connection that keeping peace and justice is repeatedly stated in the main source of Islamic law. To keep peace is, therefore, an integral part of the duties of Islamic states and it should be respected at all times.

\subsection{Making Peace}

The Qur'ann has, especially, stated the importance of the principle of peaceful international relations and Islamic states are under the juridical and theological responsibility of carrying out the contents of the relevant provisions. It is for this reason that Muslims are prohibited from conducting war which is not necessary or unjust. The Waging of war is therefore permitted in the case of self-defence or self-determination. ${ }^{19}$ It has even been emphasised that when the people who wage war are willing to make peace, one should not avoid the process of peace and writing peace treaties with them. Accordingly, 'if they are inclined to peace, make peace with them. ${ }^{20}$ Consequently, making peace in the path of Allah is almost an order for any Islamic state. Here, the word Allah does not necessarily mean God but, the way in which the whole machinery of Islamic law lays the principle of justice for the protection of the right of man and the promotion of the elements of peaceful relations.

\section{The Principle of Reciprocal Respect}

\subsection{Mutual Understanding}

Islamic international law puts an important weight on the principle of reciprocal respect. It is upon this principle that Islamic law requests not only individuals, but also states, to respect one another and not violate their rights and duties. The principle of reciprocal respect of states may not be respected if state A does not respect the rights of state B. This means that the principle of reciprocal respect of other states bases its

19 The Qur'ān, 8:56-57.

20 The Qur'ān, 8:61. 
application on mutual give and take. This principle can also be seen in the provisions of public international law within the Charter of the United Nations. The Charter encourages the implementation of the concept of respect between all states. For instance, states are obliged to respect the territorial and political independence of other states. These principles are, in fact, expressed in the provisions of the United Nations Charter as the most fundamental elements for the maintenance of equality, peace and justice. The United Nations encourages the proper understanding of international relations based on different cultural, religious, racial and traditional factors.

The Qur'ān especially encourages all Muslim states not to promote acts of hostility against other states if they are not at war with them. This principle has therefore a significant function under Islamic international law and Muslim states are obliged to respect this important principle on a mutual footing. Accordingly, 'God does not forbid you from being kind and acting justly towards those who did not fight over faith with you, nor expelled you from your homes. God indeed loves those who are just. ${ }^{21}$ In other words, states should continuously contribute to the establishment of just and fair international relations and should not violate the territorial and political independence of other states.

\subsection{Mutual Consent}

In Islamic international law, the respect of the rights of other states is a part of the international duties and obligations of states. But, it has to be reciprocal and upon freely given consent. This is also the development of the principle of brotherhood and denotes the existence of common interests for the same subject matter between various states of the world. The chief purpose of Islamic international law with the principle of the reciprocal respect of other states in international relations is, not only to encourage peaceful international relations between all states, but is also to emphasize that Islamic international law should create equality and reciprocity by mutual consent and not by force. This is the rejection of the principle of inequality. According to Islamic international law, no Islamic state is under obligation to respect the rights of other states if its own rights are not respected owing to the circumstances of the

${ }^{21}$ The Qur'ān, 60:8. Another verse of the Qur'ān reads that 'He only forbids you from making friends with those who fought over faith with you and banished you from your homes, and aided in your exile. Whoever makes friends with them is a transgressor.' 60:9. 
principle of reciprocity. The principle of reciprocal respect also extends to the binding character of international treaties including conventions, declarations, agreements, protocols and so forth. This is also true in the case of a conflict arising from the interpretation or application of the provisions of a treaty.2 The system of public international law has, also, a great respect for the principle of reciprocity concerning rights and duties based on free consent. As a rule of law, in public international law, the principle of mutual consent has a significant value within its provisions.

\section{The Principle of Self-Defence ${ }^{23}$}

\subsection{Sources of the Principle}

Islamic international law places an important value on the principle of self-defence and the principle constitutes one of the most important policies of Islamic law for the protection of individuals and states. The principle of self-defence is also one of the most well-known principles of public international law. The principle has a significant value under the domestic systems of most states and plays an effective role in the protection of individuals from all forms of violations.

Islamic international law, like the system of public international law, has certain clear provisions concerning the principle of self-defence. In fact, the basic sanction for the use of the principle of self-defence in both systems arises from two important sources. One is positive law and the other is customary law. Both these sources also have a definite function on the application of the principle of self-defence within public ${ }^{24}$ and Islamic international law.

${ }^{22}$ See also the principle of integrity of agreements in the below. One of the contemporary chief arguments relating to the possession of nuclear energy technology platforms by certain authorities in Iran is also based on the application of the principle of equal rights and obligations for all states. They motivate their arguments by stating that the rights to possession or non-possession should be applied to all states regardless of their juridical, political, economic and, military capabilities. Needless to say that possession of nuclear energies which are for military purposes should be prohibited for all states, and this should not be mistreated, even by those states, having a permanent seat in the United Nations Organization.

${ }^{23}$ See also chapter twenty-seven 3, part II.

${ }^{24}$ See Malekian, International Criminal Law, vol. I, pp. 65-68. 


\subsection{Positive Law}

In the system of public international law, the positive rules of the principle of self-defence can be found in Articles 51 of the Charter of the United Nations. ${ }^{25}$ This article has an important function within the whole system of the United Nations and has also extraordinarily significant value for the implementation of the rules of public international law. Although the provisions of this article have been the subjects of most international controversies, they present the legitimate rights of states which have been the subjects of armed attack. The article divides the rights of self-defence into two different parts. These are individual and collective defence. Accordingly, states may, depending on the circumstances, choose individual or collective defence both of which has to be reported to the Security Council of the United Nations.

Similarly, Islamic international law refers to the legitimate rights of individuals, nations and states to resort to the principle of self-defence when it is of absolute necessity. Some verses of the Qur'ān state this principle. One verse deals with the most important part of the rights of self-defence and this concerns the right of oppressed people who have been the target of unjustified acts of violation or aggression. It reads that 'Permission is granted those (to take up arms) who fight because they were oppressed. God is certainly able to give help to those.26 The aforementioned provisions are completed with the following words, 'Fight those who fight you whosesoever you find them, and expel them from the place they had turned you out from.'

The term "aggression" which is used in the main source of Islamic law applies to acts of violence which are against the principles of equalities. In other words, the concept of aggression arises whenever certain basic rights are violated and certain conditions have not been respected. For instance, there are certain rules that have to be respected by the conflicting parties during an armed conflict. Whenever a conflicting party uses

${ }^{25}$ Article 51 reads that: "Nothing in the present Charter shall impair the inherent right of individual or collective self-defence if an armed attack occurs against a Member of the United Nations, until the Security Council has taken measures necessary to maintain international peace and security. Measures taken by Members in the exercise of this right of self-defence shall be immediately reported to the Security Council and shall not in any way affect the authority and responsibility of the Security Council under the present Charter to take at any time such action as it deems necessary in order to maintain or restore international peace and security."

26 The Qur'ān, 22:39. 
much more force than is necessary during peace or the course of war, the concept of aggression may be arise. In general, aggression in public international law is also an act of violence against an established rule of law that has an important function for the maintenance of international legal order. Nevertheless, one cannot disagree with the fact that the term "aggression" is still one of the most controversial terms of international criminal law.

\subsection{Customary Law}

Another important source of Islamic international law and that of public international law governing the principle of self-defence is the provisions of customary law. It is, in fact, a consolidated principle of both systems that customary law supports the principle of self-defence and accordingly creates rights for the oppressed to fight against a serious violation or aggression.

Islamic international law like the system of international law prevents states and individuals from being aggressors. The Qur'ān clearly states that 'Fight those in the way of God who fight you, but do not be aggressive. God does not like aggressors. ${ }^{37}$ This version points to some important principles. Firstly, aggression is a crime. Secondly, to fight those who are waging conflict or war is a right. This provision implies the importance of the principle of self-defence. Thirdly, fight for justice and not for violence. Fourthly, do not be the aggressor. Fifthly, the principle of proportionality must fully be respected. Sixthly, the word God applies here to the divine jurisdiction and fairness which is against the aggressor. This means that aggressor should be prosecuted and punished without due regard to geographical position. Seventhly, the whole version denotes also the important function of a court for the implementation of justice and the founding of the truth.

\subsection{Implementation of Self-Defence}

There are some conditions for the implementation of the principle of selfdefence within both legal systems of international laws and therefore the use of the principle is not unlimited. States are, accordingly, obliged to respect certain conditions in times of imminent attack, attack and armed conflict. ${ }^{28}$ Furthermore, Islamic international law permits the use of the

27 The Qur'ān, 2:190.

28 See also the principle of proportionality. 
principle of self-defence in several other situations with due regard to the circumstances of each case. These are when a nation:

a) struggles for the purpose of self-determination,

b) fights against the unlawful occupation of its territories,

c) assists a nation in order to be released from unlawful occupation,

d) assists an oppressed nation to be released from oppressive acts of another nation,

e) assists Islamic nations in order to keep Islamic unity and solidarity,

f) participates by its armed force against an act of aggression,

g) takes measures against any form of the use of force which is considered dangerous to its territorial integrity and political independence,

h) takes measures against a state which treats its nationals badly;

j) supports a nation in order to achieve the right of self-determination,

i) struggles against all forms of colonialization,

k) struggles against discrimination,

l) struggles against apartheid and genocide,

m) struggles against terrorist attacks,

n) struggles against an attack against its political foundations

Almost all reasons in the above can be found in the system of public international law under which it permits the right to self-defence. Illustrative examples are the employment of the right of self-defence in the case of self-determination or the recognition of the rights to struggle against foreign occupation. ${ }^{29}$

${ }^{29}$ Definition of Aggression United Nations General Assembly Resolution, 3314 (XXIX)-14 December 1974. For instance, Articles 6 and 7 of the resolution reads that "Nothing in this Definition shall be construed as in any way enlarging or diminishing the scope of the Charter, including its provisions concerning cases in which the use of force is lawful." "Nothing in this Definition, and in particular article 3, could in any way prejudice the right to self-determination, freedom and independence, as derived from the Charter, of peoples forcibly deprived of that right and referred to in the Declaration on Principles of International Law concerning Friendly Relations and Cooperation among States in accordance with the Charter of the United Nations, particularly peoples under colonial and racist regimes or other forms of alien domination: nor the right of these peoples to struggle to that end and to seek and receive support, in accordance with the principles of the Charter and in conformity with the above-mentioned Declaration." 


\section{The Principle of Proportionality}

\subsection{Limitations}

The principle of proportionality is one of those principles of Islamic international law which prevents acts of aggression and oppression in the case of self-defence. Thus, this principle should be read in conjunction with the principle of self-defence under the same law. This is because the latter speaks about the right of self-defence under Islamic law, while the former limits the right by the provisions of the principle of equivalent reprisal for an act of aggression. The principle does not constitute permission for resort to aggression. Its function is to act against an act of aggression for the purpose of its prevention. Consequently, respect for the following principles has been seen as a necessary condition in the application of the principle of proportionality. These are:

i) There must be a definite sign of action which clearly constitutes a serious internationally wrongful conduct jeopardizing the security of a state.

ii) It must be definitely impossible for a state which resorts to exercising the right of self-defence to obtain protection through other legal measures such as opening negotiations, sending diplomats and/or arbitrators. In other words, all alternatives must be exhausted.

iii) The principle of proportionality must fully be respected. The principle constitutes a basic element in Islamic law of self-defence and has an important function for the identification of an act constituting an act of self-defence.

iv) An attack which is carried out for the purpose of self-defencemust be discontinued where a wrongful conduct has already been prevented or corrected.

v) A reprisal should not be considered an integral part of the right of self-defence. This is because the right of self-defence automatically comes into force against a crucial act of attack which is obvious or imminent to be committed. Thus, a state may not legitimate its conduct as self-defence for an act which has already been committed. A state has, however, the right to demand reparation.

The principle of proportionality has, also, a significant place in the system of public international law. Although a definition of the principle is not clear and may create serious confusion in cases of serious armed conflicts between several states, the principle must be regarded as one of the basic 
elements for the prevention of acts of aggression and hostility during armed conflicts. The difference between the principles of proportionality in the system of international law with that of Islamic international law is that the former permits the use of the principle of proportionality and its interpretation to the political authorities of the relevant state while the latter limits the scope of the application of the principle of proportionality to divine methods. It reads that 'Fight those in the way of God who fight you, but do not be aggressive. ${ }^{30}$ This means that a state has to be very cautious in the case of resorting to the right of self-defence and the use of the principle of proportionality should not be violated by any Islamic state.

\subsection{Applications}

The principle of proportionality may also coincide with the principle of equivalent reprisal. A reprisal should not violate the principle of proportionality of Islamic international law and public international law. Islamic international law prohibits acts of reprisal which are oppressive and aggressive. The main source of the law reads that 'Fighting during the holy month (if the sanctity) of the holy month (is violated) is (just) retribution. So if you are oppressed, oppress those who oppress you to the same degree, and fear God, and know that God is with those who are pious and follow the right path. ${ }^{31}$ In another verse the Qur'an provides some provisions for those who are aggressors conducting war against the oppressed. It states that 'If they (enemies) desist, then cease to be hostile, except against those who oppress. ${ }^{32}$ In other words, the use of the principle of self-defence and the application of the principle of proportionality should not be brutal or oppressive. However, the right to resort to self-defence is prolonged, as long as the oppressive acts are continued. Thus, there is no special time limit to acts of defence against those who are aggressors and continuously conducting aggressive acts.

\subsection{Misinterpretation of the Principle}

One cannot, however, deny the fact that the principle of proportionality has been misinterpreted and wrongly resorted to under both systems

\footnotetext{
30 The Qur'ān, 2:190.

31 The Qur'ān, 2:194.

32 The Qur'ān, 2:193.
} 
of international law. Political and economic factors have been two of the most essential reasons for this wrongful use of the principle. This is because, although both systems of international law provide certain provisions for the use of the principle of self-defence, as well as the principle of proportionality, political authorities have had decisive role in the application of these principles. One important factor may be that international laws in both systems have not necessarily been enforced for juridical purposes but exclusively for the interests of the political consequences of a given case.

\section{The Principle of Integrity of Agreements}

\subsection{Pacta Sunt Servanda}

Islamic international law places a significant weight and respect on the juridical characterization of international agreements. The principle of the integrity of international agreements in Islamic international law is, strictly speaking, pacta sunt servanda. ${ }^{33}$ It is for this reason that Muslims are legally obliged to implement and fulfil the provisions of treaties or agreements concluded between Muslims and non-Muslim communities. The principle of the integrity of agreements and full respect of their provisions in Islamic international law is principally based on the provisions of the Qur'än. According to it, the provisions of a treaty must be fulfilled and parties to a treaty are consequently under a legal duty to carry out their treaty obligations.

In the system of public international law, the principle of pacta sunt servanda constitutes one of the most important principles of the law of international treaties. This can also be seen in the Vienna Convention on the Law of Treaties of 1969. According to the Convention, contracting parties are under conventional duties to carry out their obligations in good faith. Although customary and conventional international laws require states to fulfil their conventional obligations, the principle of pacta sunt servanda may be disregarded by another principle of public international law namely rebus sic stantibus. This means that the fundamental change of circumstances may invalidate the obligations given in a treaty. ${ }^{34}$ Sim-

\footnotetext{
${ }^{33}$ For the law of treaties under Islamic international law see the relevant chapter.

34 Article 62 of the Vienna Convention concerning the fundamental change of circumstances reads that

"1. A fundamental change of circumstances which has occurred with regard to those
} 
ilarly, in the system of Islamic international law, a treaty provisions may not be fulfilled by a contracting party, if another party does not fulfil its obligations.

\subsection{Integrity of Given Obligations}

The principle of the integrity of agreements under Islamic international law can especially be understood from one of the most significant verses of the Qur'a $n$ which emphasizes the importance of respecting the obligations of a covenant. The verse specifies that 'Fulfil your covenant with God, having made the covenant, and do not break your oaths once you have sworn them, as you have made God a witness over you.' ${ }^{35}$

In Islamic international law, a treaty establishes rights, duties and obligations for the parties and contracting parties should carry out their given obligations. The Qur'ann especially states that 'Except those idolaters with whom you have a treaty, who have not failed you in the least, nor helped anyone against you. Fulfil your obligations to them during the term (of the treaty). ${ }^{36}$ One important point of this verse is that it encourages the contracting parties to a treaty to carry out their obligations to the end of their terms.

It is important to emphasize that for all parties to a treaty, the provisions are only fulfilled on an equal footing. This means that mutual respect of the provisions of the relevant treaty is the basic reason for the fulfilment of its obligations. When the provisions of a treaty are not respected or are violated by one of the contracting parties to the treaty,

existing at the time of the conclusion of a treaty, and which was not foreseen by the parties, may not be invoked as a ground for terminating or withdrawing from the treaty unless:

(a) the existence of those circumstances constituted an essential basis of the consent of the parties to be bound by the treaty; and

(b) The effect of the change is radically to transform the extent of obligations still to be performed under the treaty.

2. A fundamental change of circumstances may not be invoked as a ground for terminating or withdrawing from a treaty:

(a) if the treaty establishes a boundary; or

(b) if the fundamental change is the result of a breach by the party

invoking it either of an obligation under the treaty or of any other international obligation owed to any other party to the treaty.

3. If, under the foregoing paragraphs, a party may invoke a fundamental change of circumstances as a ground for terminating or withdrawing from a treaty it may also invoke the change as a ground for suspending the operation of the treaty."

35 The Qur'àn, 16:91.

36 The Qur'àn, 9:4. 
there will be no obligation on other parties to carry out the given obligations to the treaty concerning the violating party. ${ }^{37}$ Similar provisions can easily be observed in the system of international law. ${ }^{38}$

\subsection{Proper Consent}

Another important matter in the systems of Islamic international law and public international law is that treaties should be concluded according to proper consent. A treaty which has been imposed by one state on another without the accurate consent of the latter, does not establish conventional obligations for that state and such a treaty is therefore invalid. Treaties which are concluded through fraud, misleading representation by the parties or other inappropriate behaviour are not valid and therefore do not create rights and obligations for the parties. ${ }^{39}$ Provisions of treaties which are imposed by the use of force have not either the legal effect of international treaties and are therefore invalid. Thus, consent appears to be one of the most important principles for the conclusion of international treaties and this principle is one of the chief conditions of the law of treaties in Islamic and public international law.

\section{The Principle of Justice}

\subsection{Qualified Values}

Islamic international law essentially bases its social value on the principle of justice. In fact, this principle has important functions within the Islamic system and constitutes an integral part of Islamic jurisdiction. Islamic states are obliged not to ignore this principle and should implement the principle in their international conducts fully. This includes both in war and peacetimes. The principle of justice in Islamic law generally consists of moral, legal and theological values. All these values also benefit substantially from divine jurisprudence. By moral value, we do not necessarily mean that the law is based on the expression of moral necessities and emotional feelings, but, on the principles of natural and positive law. (55)

37 The Qur'ān, reads that 'How could there be a treaty between idolaters and God and His Apostle, except those you covenanted by he Sacred Mosque? Therefore as long as they are honest with you be correct with them, for God loves those who are godly.' 9:7.

38 Consult Ian Brownlie, Principles of Public International Law (2008).

${ }^{39}$ See the relevant chapter. 
Islamic international law calls on all Islamic states and nations to be just and not to violate the principle of justice, even when, there have been serious violations of their rights by other states or nations. This principle within Islamic international law encourages the peaceful settlement of international disputes and consequently prevents wars in international relations. It is therefore of fundamental importance that all international conflicts be resolved through justice and fairness. The disappearance of justice can disqualify all actions of human beings. ${ }^{40}$

\subsection{Human Qualification}

On the whole, the principle of justice in the Islamic system not only applies to the sense of human morality at a given time, but also, to human substance, nature, wisdom and consciousness and also to the attitude governing the general behaviour. ${ }^{41}$ Appropriate justice in Islam belongs to the jurisdiction of God-all other justices are subject to human qualification. It is for this reason that Islamic international law places a significant demand on justice, basing its principles of jurisdiction on principles which are already accepted by an overwhelming majority of states through appropriate and pure consent e.g. the principles within the Statute of ICC.

There must be a balanced and unbiased presentation of regulations by any relevant jurisdiction and judge. Islamic law emphasizes that even when a person is guilty of violations; he/she should be brought with priority under the jurisdiction that concerns his own theological concept. This means that the Islamic jurisdiction should not be enforced by force of law but human will and choice. ${ }^{42}$ The Qur'ān (the basic source),

40 The Prophet often stated that 'Acts will be 'judged' only according to motives.' Consult also El Din Attia Gamal, 'The Right to a Fair Trial in Islamic Countries', in David Weissbrodt and Rüdiger Wolfrum (eds.), The Right to a Fair Trial (1997), at pp. 343371 .

${ }^{41}$ There are several important principles relating to the general behaviour of a life of a person. It is asserted that Ali, one of the first four Caliphs (these are Abu Bakr, Umar, Uthman, and Ali) asked the Prophet about these principles. The Prophet replied that 'Knowledge is my capital, reason is the basis of my religion, desire is my mount for riding, remembrance of God is my comrade, confidence is my treasure, anxiety is my companion, science is my arm, patience is my mantle, contentment is my booty, modesty is my pride, renunciation of pleasure is my profession, certitude is my food, truth is my intercessor, obedience is my grandeur, struggle is my habituate and the delight of my heart is in prayer.'

${ }^{42}$ Due to the Qur'an and the practice of Caliphs and opinion of Islamic jurists, nonMuslims have many rights which should be respected by national authorities. These are such as "1. right to life, personal safety, and respect; 2. freedom of religion; 3. right to 
the Hadith (the second source) and 'the practice of all time demand that non-Muslims should have their own laws, administrated in their own tribunals by their own judges, without any interference on the part of the Muslim authorities, whether it be in religious matters or social. ${ }^{43}$ The concept of appropriate jurisdiction has also been developed in Islamic international law with analogy to the concept of jurisdiction in Islam. This means that when there is a question of the establishment of jurisdiction over a person who has a designated social position such as diplomats and protected persons, the rights of such persons should not be ignored. ${ }^{44}$

\section{The Principle of Diplomatic Immunity}

\subsection{Evolution of Immunity}

There are many rules regarding the immunity and protection of individuals under Islamic international law. ${ }^{45}$ Diplomatic immunity and protection is regarded as one of the most predominant principles of the law for the development and consolidation of peaceful international relations between various nations. This principle was in fact practised in the diplomatic relations of the Prophet with other nations and the respect for this principle achieved a high level of applicability at that time. ${ }^{46}$

The principle of diplomatic immunity and protection is regarded as an integral part of Islamic customary international law. This custom came into existence with the practice of the Prophet and was later developed by the Caliphs whose practices were considered as a part of Siyar ${ }^{47}$ or the Islamic international relations of approximately one thousand four hundred years ago. Contrary to Islamic international law, diplomatic immunity in public international law is mostly the development of the law during the twentieth century and its consolidation has not effectively

\footnotetext{
justice and equality before law; 4 . freedom of expression; 5. right to political representation; 6 . freedom of movement, assembly, and association; 7. right to education; 8 . right to social security; 9. right to property; 10 . right to government service; 11 . right to exemption from compulsory military service; etc." www.islamicity.com/articles/Articles .asp?ref=DW-0603-2948. Visited on 2009-10-14.

${ }_{43}$ Publications of Centre Culturel Islamique-Introduction to Islam, p. 40.

${ }^{44}$ See chapter on diplomatic immunities.

${ }^{45}$ See the relevant chapter.

46 The principle of immunity is also considered a part of diplomatic mission's dignity.

47 Hamidullah, The Muslim Conduct of State, p. 21.
} 
been possible before this time. Nevertheless, a considerable number of rules concerning diplomatic protection in public international law have been borrowed from its customary rules. ${ }^{48}$ This is because the system of customary international law has encouraged the legal, criminal and political immunities of diplomats.

\subsection{Scope of Recognition}

The customary rules of diplomatic protection and immunity in Islamic international law may be compared with the customary rules of public international law. The difference between these two systems of law concerning diplomatic protection is basically the fact that most relevant rules of public international law are innovations of the twentieth century while the relevant rules of Islamic international law are manifestations of Islamic rules practised since the revelation of Islam by the Prophet and eventually developed in the course of Islamic jurisprudence. ${ }^{49}$ Even though rules of Islamic international law governing diplomatic protection are as old as Islamic theology itself, they are, more or less, equivalent to contemporary rules of diplomatic protection under public international law.

In Islamic international law as in public international law, protection and immunity inter alia relates to matters of diplomats and their family lives, the protection and immunity of their baggage, home, any inferiors working under their offices, their religions and their relevant practices as well as the locality of their missions..$^{50}$

One of the most important immunities and protections of diplomats under Islamic international law relates to the matter of jurisdiction over diplomats. This type of protection has had a significant function in the development and consolidation of diplomatic relations between Islamic and non-Islamic states. ${ }^{51}$

The protection of diplomats in public international law on the matter of jurisdiction overlaps, in many aspects such as civil and criminal cases, with that of Islamic international law. However, each area of law has its own type of jurisdiction and applies with certain conditions and under

48 See also the relevant chapter in part II.

49 See the relevant chapter.

${ }^{50}$ Immunities and protections are also for the victims of religious, political, racial or other persecutions. Therefore, refugees have good shelter under the jurisdiction of Islamic international law. See infra.

${ }^{51}$ See the relevant chapter in part II. 
particular political circumstances. Moreover, the sources of one area of law are very old and are theological while the sources of international law are, generally speaking, the modern ratifications of international conventions including customary international law.

\section{The Principle of Unity of Muslims}

\subsection{Unity of Nations}

In principle, Islamic law emphasizes the unity of Islamic nations and is of the view that Muslim populations in essence constitute a single community. This idea of Islam can obviously be found within its international law denoting the universality of divine jurisdiction. The principle of unity of Muslims aims to bring all Muslims under one law and one jurisdiction and simultaneously spread the advantages of brotherhood, peaceful international relations, equality of interests in religions, politics as well as laws, and justices. This unity of Islamic nations may be seen within the principles of the Charter of the Organization of Islamic Conference. It states that

1) total equality between member states;

2) respect of the right of self-determination, and non-interference in the domestic affairs of member state;

3) respect of the sovereignty, independence and territorial integrity of each member state;

4) settlement of any conflict that may arise by peaceful means such as negotiation, mediation, reconciliation or arbitration;

5) abstention from the threat or use of force against the territorial integrity, national unity or political independence of any member State. ${ }^{52}$

The principle of unity of Muslims can especially be understood from one of the verses of the Qur'ān which denotes this important event. According to this verse, all human beings belonged to one community, but this was changed, at a later date. ${ }^{53}$ This principle should not however be misunderstood by the reader. This is because Islamic principles of unity do not encourage discrimination and privileges for any nation over

${ }^{52}$ Article 1 (B) of the Charter of the Conference.

53 The Qur'än, 2:213. 
another. It is rather the basic principle of Islamic theory that all Muslims are brothers and that all human beings should live in brotherhood and equal justice. The principle of Unity of Islamic nations can be compared with the principles of the European Union. Of course, one of the most obvious differences between these two systems is that one is based on a legislative treaty concluded in the twentieth century while the other on moral and natural principles of law. Obviously, the former is the modern institute of law, politic, economy and ethic in Europe. Otherwise both systems of law encourage more or less the following principles:

- respect of fundamental human rights;

- individuals should be treated in accordance with the law and legal orders;

- individuals should be respected by their respective governments;

- nationality or citizenship of each member is recognised by the member states;

- the voice and rights of the members should be given sufficient attention by other countries;

- development of friendly relations between the members of the union;

- assistance and cooperation in different matters of social and economic interests;

- creation of security and justice for the individuals and members themselves;

- assistance for the promotion of justice and peace;

- respects of the rights of members of the union;

- military cooperation in certain necessary conditions;

- promotion of social and economic progress between member states;

- financial assistance to states which have weak economic stability in the union;

- protection of each member from any form of antagonism.

\subsection{The Purpose of Unity}

One of the important aspects of the principle of unity of Muslims is that it creates peaceful relations between Islamic states and prevents conflicts and acts of aggression. The principle therefore highlights the fact that no Islamic nation or state should resort to aggressive conduct. Moreover, it sanctions all Muslims to contribute to the maintenance of Islamic justice, equality and brotherhood, to make available assistance, and if necessary, 
armed forces in order to prevent acts of aggression. It is the duty of Islamic states/nations to impose retribution on the aggressive state to wipe out damages.

This principle of unity of Muslims in order to facilitate acts of assistance to an oppressed nation is clearly stated in the Qur'ann. It reads that 'If two groups of believers come to fight one another, promote peace between them. Then if one of them turns aggressive against the other, fight against the aggressive party till it returns to God's authority. If it does so, make peace among them equitably and be impartial. ${ }^{54}$ It is evident that Islamic law puts a significant value on the objectivity of justice and arbitrations in different matters and this principle should especially be respected in the case of a judgement relating to the matter of aggression.

\subsection{Interpretation of Unity}

The principle of the unity of Muslims should not be misinterpreted and should be compared with Chapter VII of the Charter of the United Nations relating to action with respect to threats to the peace, breaches of the peace and acts of aggression. ${ }^{55}$ This is because the principle of the unity of Muslims prevents any act which may be a threat to Islamic peace, breach of Islamic unity, act of aggression and brotherhood ideologies. It also simultaneously prevents acts of aggression and aggressive war. The difference between these principles of Islamic international law with that of public international law expressed under Chapter VII of the United Nations may be in the form and character of authorization. The power of the latter arises from the contribution through membership by a large number of states to the Organization and their political relations with the permanent members of the United Nations while the power of the former arises from brotherhood, equality and justice including human morality and the divine jurisdiction.

Islamic relevant provisions are self-conductive while the latter may or may not be self-conductive depending on the circumstances and the views expressed by the Security Council of the United Nations. Moreover, the implementation of the relevant provisions of the United Nations depends on political consideration while the relevant provisions

\footnotetext{
54 The Qur'ān, 49:9.

${ }^{55}$ On chapter VII of the Charter of the United Nations see Farhad Malekian, The Monopolization of International Criminal Law in the United Nations: A Jurisprudential Approach (1995).
} 
of Islamic international law is based on the notion that the unity of Muslims should not tolerate aggressive conducts which are against brotherhood, equality and justice. ${ }^{56}$ The Qur'a $n$, the basic source of Islamic and Islamic international law reads in this context that 'The faithful are surely brothers; so restore friendship among your brothers, and fear God that you may be favoured. ${ }^{57}$ This verse strongly encourages the principle of peaceful relations between Muslims and settlement of their conflicts through peaceful channels. ${ }^{58}$

\footnotetext{
56 This does not necessarily mean that the unity of Islamic states is not permitted to act against an aggressive conduct which is carried out against a non-Muslim nation/state.

57 The Qur'ān, 49:10.

58 The system of Security Council of the United Nations has been proved not to be healthy in international context. It has been misused for the purpose of fulfillment of interests of powerful states. For instance, the authority of the organization was monopolized by the United States and the United Kingdom to illegally invade the Iraqi territory. This brought by itself serious violations of international criminal law by the two permanent members of the United Nations. None of these members have been brought before an international court for prosecution and punishment. The recent show in the United Kingdom behind the government authority against Tony Blair demonstrates these criminal conducts of the big powerful nations. The fact is that "Tony Blair is directly responsible for the massacre of tens of thousands of innocent Iraqi, Afghani and Palestinian civilians. During his time in power he acted as George Bush's puppet, and reinforced the imperialistic and repressive measures against these countries and their people. It is estimated that up to 28,000 Afghani civilians have been killed as a result of foreign military actions since the beginning of the war in 2001, and it is estimated that around 100,000 Iraqi civilians have been killed as a result of US led attacks between 2003 and now." Hundreds protest war-criminal Tony Blair in Dublin (2010-09-04), www.wsm.ie/c/dublin-protestwar-criminal-tony-blair.
} 